\title{
Disinfection and reduction of organic load of sewage water by electron beam radiation
}

\author{
Y. Avasn Maruthi • N. Lakshmana Das • \\ Kaizar Hossain · K. S. S. Sarma · K. P. Rawat • \\ S. Sabharwal
}

Received: 17 March 2011 / Accepted: 18 July 2011/Published online: 5 August 2011

(C) The Author(s) 2011. This article is published with open access at Springerlink.com

\begin{abstract}
The efficacy of electron beam radiation for the disinfection and reduction of organic load of sewage water was assessed with ILU-6 Accelerator at Radiation Technology Development Division of the Bhabha Atomic Research Centre, Mumbai India. The current problem on environmental health in relation to water pollution insists for the safe disposal of sewage water. In general, sewage water comprises heterogeneous organic based chemicals as well as pathogens. EB treatment of the wastewater has found to be very effective in reducing the pathogens as well as organic load. EB dose of $1.5 \mathrm{kGy}$ was sufficient for complete elimination of total coli forms. The experimental results elucidated the reduction of biological oxygen demand-BOD (35 and $51.7 \%$ ) in both inlet and outlet sewage samples. Similarly reduction of chemical oxygen demand-COD was observed (37.54 and 52.32\%) in both sewage samples with respect to increase in irradiation doses $(0.45-6 \mathrm{kGy})$. The present study demonstrated the potential of ionizing radiation for disinfection of sewage and to increase the water quality of the wastewater by decreasing BOD and COD. So, the irradiation sewage water can find its application either in agriculture for irrigation, in industry for cooling purpose and some selected domestic purposes.
\end{abstract}

Y. A. Maruthi $(\bowtie) \cdot$ N. L. Das · K. Hossain

Department of Environmental Studies, GIS, GITAM Institute

of Science, GITAM University, Visakhapatnam

530045, Andhra Pradesh, India

e-mail: ymjournal03@yahoo.co.in

K. Hossain

e-mail: kaizar.kazar@gmail.com

K. S. S. Sarma · K. P. Rawat · S. Sabharwal Radiation Technology Development Division, Bhabha Atomic Research Centre (BARC),

Mumbai 400085, India
Keywords Coliform and organic load of sewage water . Electron beam radiation

\section{Introduction}

Population and development pressures have made waste water treatment an important component of environmental pollution control alleviation. In India, major cities generate large volumes of wastewater due to their inefficient water management systems. Large amounts of wastewater that can be reused, is let down into either sewerage drains or near by aquatic resources. Furthermore, the potential for environmental pollution is greater due to high quantity of waste materials produced namely the organic matter (Shathele 2009), generally rich in pathogens of faecal origin, even after the treatment with conventional methods. Few important pathogens in sewage water namely bacteria (E. coli, Salmonellae sp.), viruses (e.g. Poliovirus) and protozoans are causing various types of diseases especially of faecal oral route (Jianlong Wang and Jiazhuo Wang 2007). Therefore, to protect health and the environment, new approaches should be adopted to overcome this grim situation, including remediation and the reuse of wastewater. Although it is under scrutiny, chlorine is still widely used as chemical disinfectant for the treatment of wastewater. Treated water discharged from sewage treatment plant can be reused for irrigation. Prescribed water quality standards for recreational and other water uses, such as shellfish production, are typically based on contamination levels as indicated by number of faecal coliforms in effluents. Recently, application of ionizing irradiation, especially electron beam radiation that is generated from electron beam accelerator to treat sewage water has attracted the environmentalists. Chief advantage of 
electron beam radiation over existing chemical treatments derives from its short wavelength and its ability to penetrate into the tissues. It was reported that ionizing radiation induces both the degradation of numerous compounds and the inactivation of microorganisms in sewage on irradiation, depending on the type of energy, dose rate and absorbed radiation (Klieber et al. 2002; Drzewicz and Gehringer 2005; Casimiro et al. 2008).

In water as well as wastewater, the principal component is water. Therefore, it would be expected that the effect of ionizing radiation might be dominated by interaction of radiation and water (Meeroff Daniel et al. 2004). As far as pure water is concerned, when exposed to ionizing radiation, the radiolysis of water can be presented as following equation (Spinks and Woods 1990):

$$
\begin{aligned}
\mathrm{H}_{2} \mathrm{O} \rightarrow & {[2.7] \mathrm{OH}^{*}+[2.6] \mathrm{e}_{\mathrm{aq}}^{-}+[0.6] \mathrm{H}^{*}+[2.6] \mathrm{H}_{3} \mathrm{O}^{+} } \\
& +[0.7] \mathrm{H}_{2} \mathrm{O}_{2}+[0.45] \mathrm{H}_{2}
\end{aligned}
$$

So if we consider pure water, each $100 \mathrm{eV}$ absorbed by water will result in the generation of 2.7 radical $\mathrm{OH}^{*}, 2.6$ $\mathrm{e}_{\mathrm{aq}}^{-}, 0.6$ radical $\mathrm{H}^{*}, 2.6 \mathrm{H}_{3} \mathrm{O}^{+}, 0.7$ molecule of $\mathrm{H}_{2} \mathrm{O}_{2}$ and 0.45 molecule of $\mathrm{H}_{2}$ (Borrely et al. 1998a, b).

Powerful oxidizing and reducing species (e.g., $\left.\mathrm{OH}, \mathrm{e}_{\mathrm{aq}}^{\mathrm{A}}, \mathrm{H}\right)$ and molecular products (e.g., $\mathrm{H}_{2}, \mathrm{H}_{2} \mathrm{O}_{2}$ ) are produced due to the interaction between radiation and water, so these chain reactions lead to the phenomenon as described earlier by Parker and Darby (1995) and Sommers and Glenn (2006).

Initial research at the electron beam facility focused on bacterial disinfection at the large scale (Farooq et al. 1993) as well as the effect of electron beam irradiation on waste water characteristic such as biological oxygen demand (BOD) and chemical oxygen demand (COD). Therefore, the effects of electron beam irradiation on the inactivation of microorganisms, mainly on the pathogens, as well as reduction of organic load present in sewage water were investigated.

\section{Methods}

The water samples were collected from sewage water treatment plants (A \& B), Mumbai (inlet area from where raw sewage is entering into the plant and outlet i.e. prior to chlorination). The samples were brought to the laboratory with the help of sterile plastic bottles, kept in ice boxes and analysed for $\mathrm{BOD}_{5}, \mathrm{COD}$ and total microbial count by adopting standard procedures (APHA 2005).

Irradiation of sewage water

A laboratory scale study has been carried out regarding the possibility of electron beam application for sewage water disinfection and reduction of BOD and COD. To carry out the experiment, the stainless steel belt conveyor was constructed for irradiation under continues flowing condition. The width and depth of water container was designed to be 60 and $0.7 \mathrm{~cm}$, respectively, which was fit to the penetration range of experimental accelerator. The rate of sewage water moving through conveyor belt was controlled in $\sim 3,000 \mathrm{cc} / \mathrm{min}$, which treat up to $1.5 \mathrm{~m}^{3} / \mathrm{h}$. The radiation experiment was carried using ILU-6 Accelerator (ILU-6 pulse Accelerator parameters are shown in Table 1), at Electron Beam Facility of the Radiation Technology Development Division of the Bhabha Atomic Research Centre, Mumbai, India. Then all samples were analysed for same parameters after EB treatment at different doses $(0.45,0.75,1.5,3,4.5$ and $6 \mathrm{kGy})$ at room temperature.

Microbial count

Plate count method was used to enumerate the microbial count. The Hi-Media Plate count Agar (M091-500G) was used for total bacterial count, Hi-Media MacConkey Agar (M081A) for coliforms and Hi-Media Salmonella-Shigella Agar (M108) for total Salmonella-Shigella. The wastewater samples were diluted in Phosphate buffer (Hi-Media M 461) and were used on spread plate method on agar, then incubated at $37^{\circ} \mathrm{C}$ until colony formation was observed.

\section{Results and discussions}

The effect of electron beam radiation on coliform and the decomposition of organic materials in sewage water were evaluated as a function of absorbed dose by determining the change of microbial load, biological oxygen demand and chemical oxygen demand. As shown in Figs. 1, 2, 3, 4, 5, 6, 7, 8 and Table 2 .

\section{EB treatment act as disinfectant}

The mechanism of killing the pathogens depends largely on the nature of the disinfectant and on the type of microorganism. In general, four mechanisms are proposed to

Table 1 ILU-6 pulse accelerator parameters during the experiment

\begin{tabular}{ll}
\hline Energy & $2 \mathrm{MeV}$ \\
Average beam current & $1.2 \mathrm{~mA}$ \\
Pulse repetition frequency & $10 \mathrm{~Hz}$ \\
Conveyor speed & $\sim 10 \mathrm{~cm} / \mathrm{s}$ \\
Pulse current & $250 \mathrm{~mA}$ \\
Pulse accelerator duration & $\sim 500 \mu \mathrm{S}$ \\
\hline
\end{tabular}

The dosimetry study was carried out using FWT60 radio chromic films calibrated by Graphite Calorimeter 
Fig. 1 Inactivation of microorganisms by radiation (treatment plant-A, inlet sample)

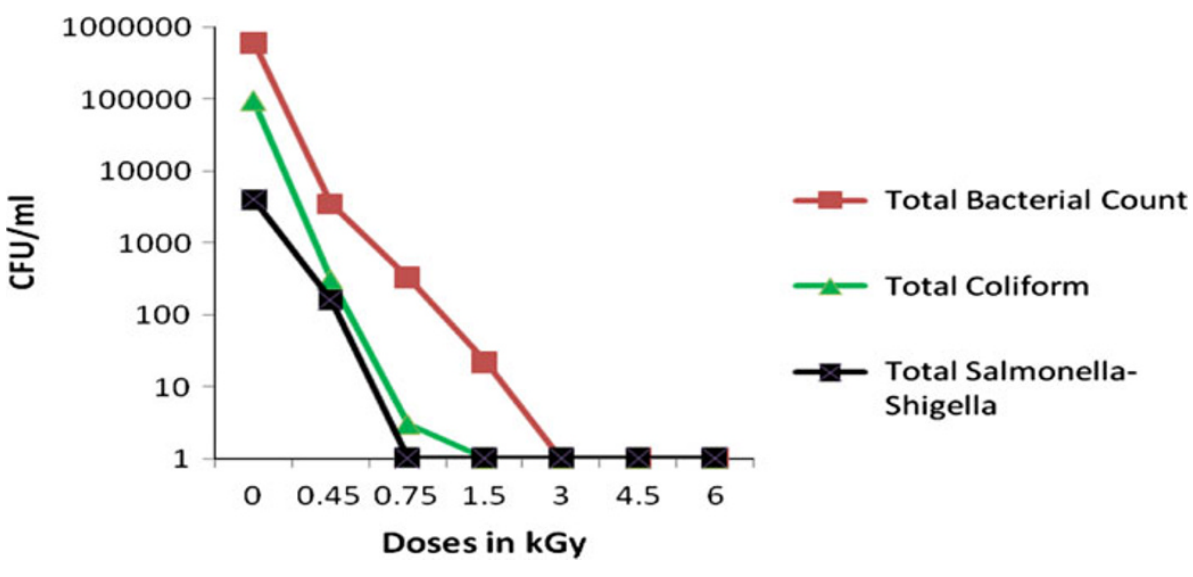

Fig. 2 Inactivation of microorganisms by radiation (treatment plant-A, outlet before chlorination, sewage sample)
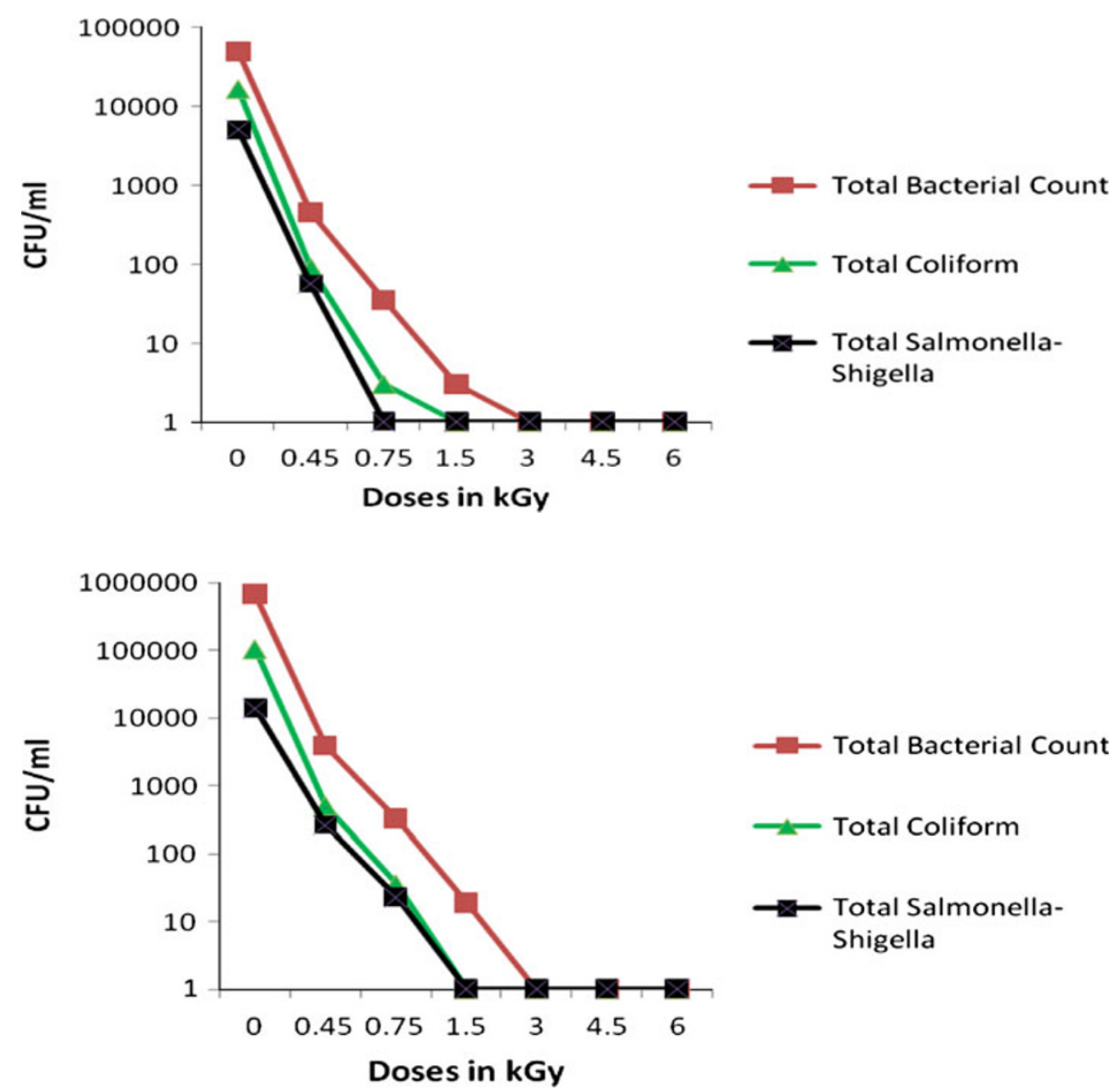

Fig. 3 Inactivation of microorganisms by radiation (treatment plant-B, inlet sample) explain the destruction or inactivation of organisms, damage to cell well, alteration of cell permeability, changing the colloidal nature of the cell protoplasm and inactivation of critical enzyme systems responsible for metabolic activities.

Several samples were obtained from the plant to examine the inactivation of microorganisms with radiation technology. Figures 1, 2, 3, and 4 show the inactivation of total and faecal coliforms (organisms per $\mathrm{ml}$ ) in the raw inlet and unchlorinated outlet water samples. Our study observed that both total and faecal coliforms were reduced to below detection limit. The total bacterial count reduced from $6.1 \times 10^{5}$ to 0 at $3.0 \mathrm{kGy}$, total coliforms count reduced from $9.6 \times 10^{4}$ to 3 at $0.75 \mathrm{kGy}$ and total Salmonella-Shigella count reduced from $4 \times 10^{3}$ to 0 at $0.75 \mathrm{kGy}$ in the case of treatment plant-A, inlet sewage water sample and total bacterial count reduced from $4.8 \times 10^{4}$ to 0 at $3.0 \mathrm{kGy}$, total coliforms count reduced from $1.6 \times 10^{4}$ to 1 at $1.5 \mathrm{kGy}$ and total Salmonella-Shigella count reduced from $5 \times 10^{3}$ to 0 at $0.75 \mathrm{kGy}$

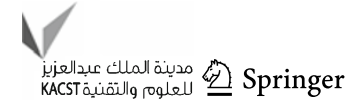


Fig. 4 Inactivation of microorganisms by radiation (treatment plant-B, outlet before chlorination, sewage sample)

Fig. 5 Effect of radiation on BOD and COD (treatment plant-A, inlet sample)
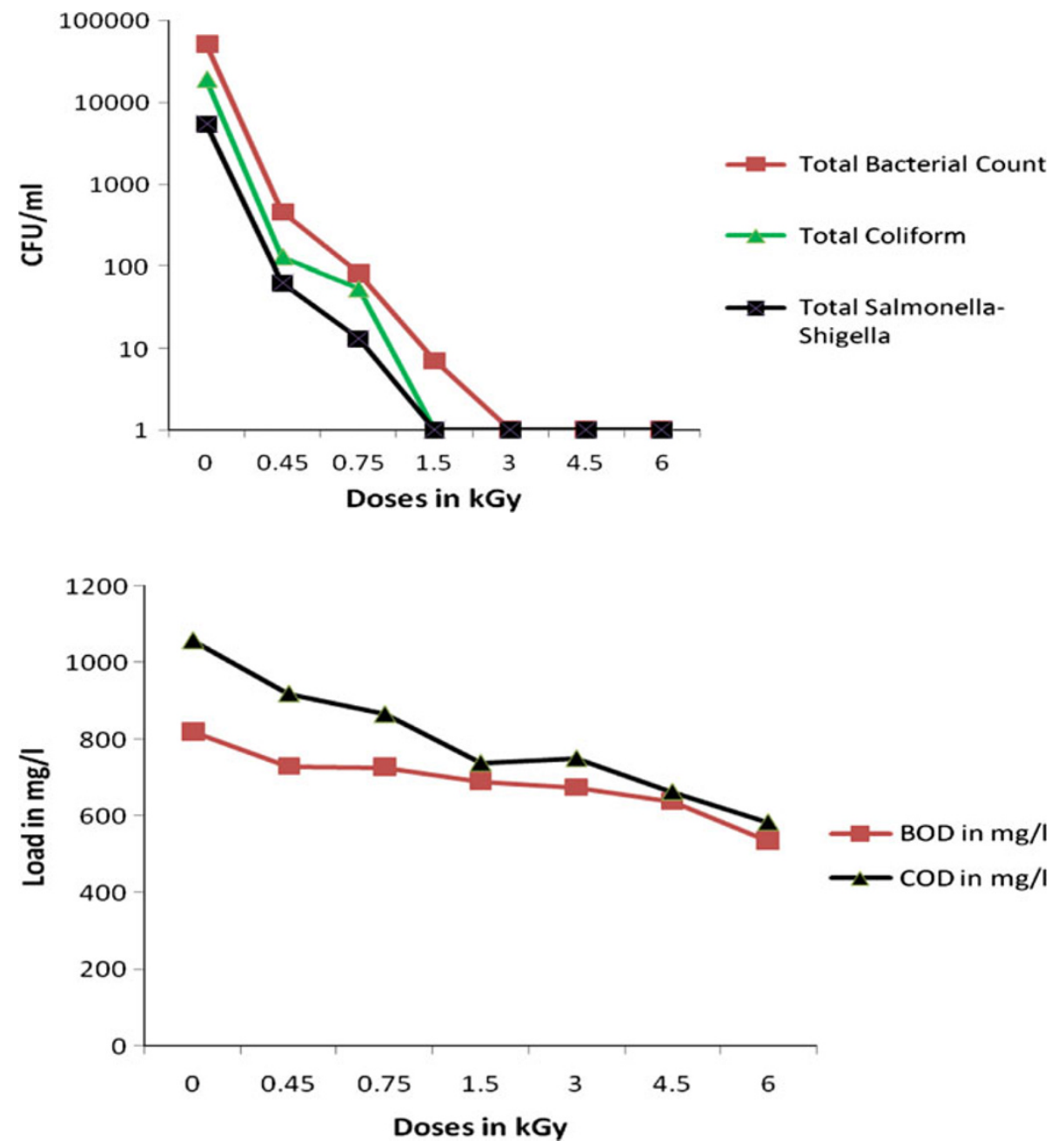

Fig. 6 Effect of radiation on BOD and COD (treatment plant-A, outlet sample)

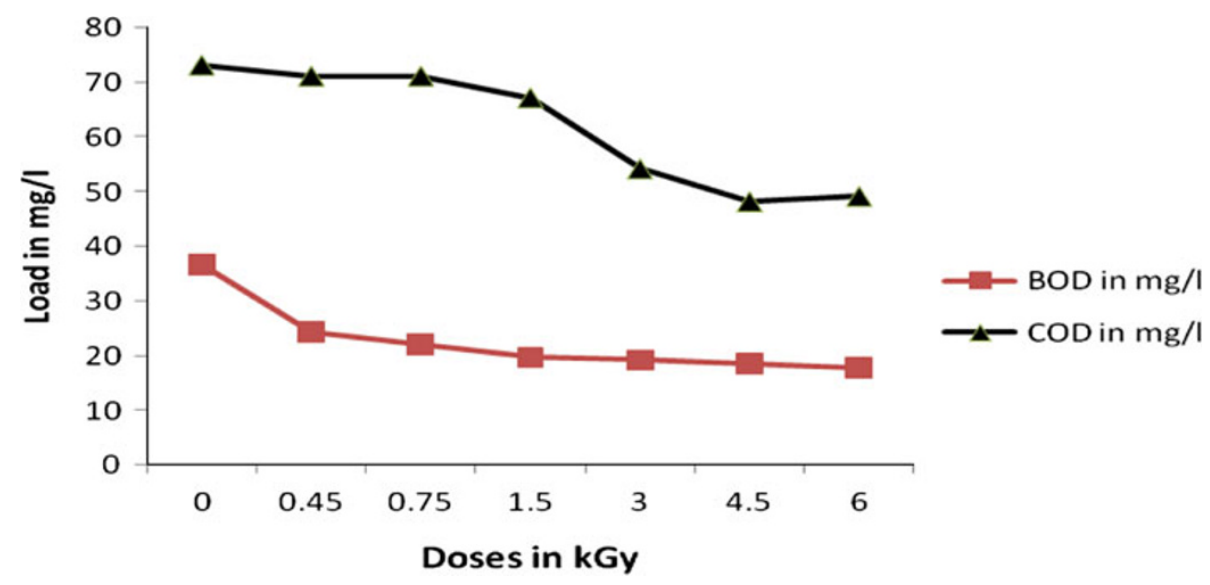

(Figs. 1, 2). Similarly for inlet sample of treatment plant-B, the total bacterial count reduced from $6.8 \times 10$ to 0 at $3.0 \mathrm{kGy}$, total coliforms count reduced from $10.6 \times 10^{4}$ to 36 at $0.75 \mathrm{kGy}$ and total Salmonella-Shigella count reduced from $1.4 \times 10^{4}$ to 23 at $0.75 \mathrm{kGy}$ and for outlet samples total bacterial count reduced from $5.2 \times 10^{4}$ to 0 at $3.0 \mathrm{kGy}$, total coliforms count reduced from $1.9 \times 10^{4}$ to 1 at $1.5 \mathrm{kGy}$ and total Salmonella-Shigella count reduced from $5.4 \times 10^{3}$ to 13 at $0.75 \mathrm{kGy}$ (Figs. 3, 4).

Radiation effects on microorganisms are not only associated with the chemical changes but are also dependent on physical parameters such as dose rate, dose distribution, 
Fig. 7 Effect of radiation on BOD and COD (treatment plant-B, inlet sample)
Fig. 8 Effect of radiation on BOD and COD (treatment plant-B, outlet sample)
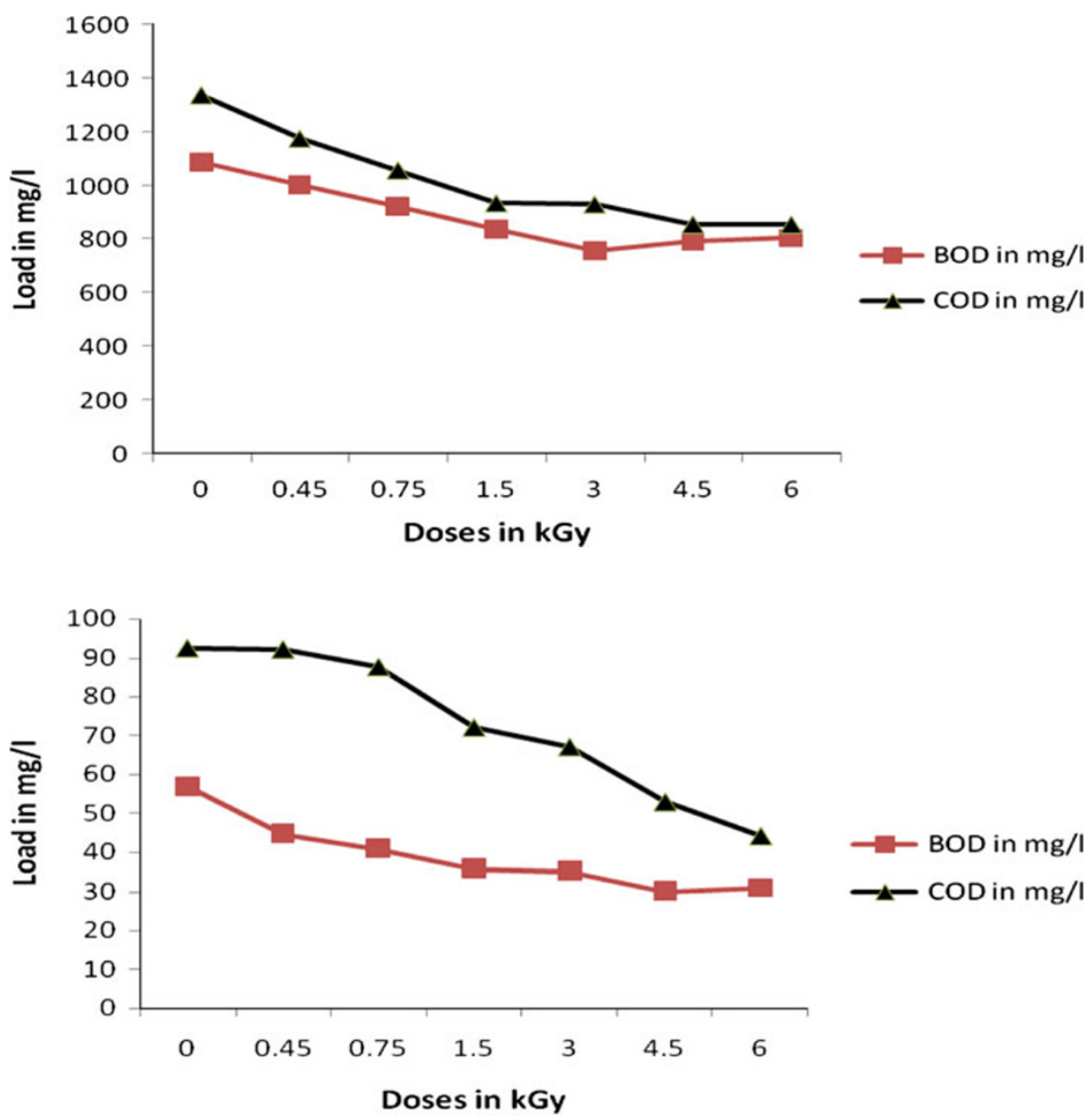

radiation quality, radiation type and exposure pattern and physiological factors like growth phase, sensitivity, number of microorganisms etc. The action of radiation on a living organism can be divided into direct and indirect effect. If the radiation interacts with the atoms of the DNA molecule or some other cellular component critical to the survival of the cell, it is a direct effect, which will eventually affect the ability of the cell to reproduce and survive. The formation of major radiolysis products from water and their subsequent interactions with waste particles are described as indirect effect, which is generally caused by energy deposition in the medium resulting in the formation of secondary reactants generated through free radicals production, sensitizer and secondary ionization (Borrely et al. 1998a, b).

The gross appreciation of radiation effects on microorganisms is due to two main parameters. (a) The lethal dose at which all the microorganisms are killed or inactivated. (b) The $\mathrm{D}_{10}$ value that corresponds to the dose at which the number of viable microorganisms present in the initial medium is decreased by $1 \log$. The radiation dose required to inactivate the pathogenic bacteria is generally defined in terms of the $D_{10}$ value, which is the radiation dose required to
Table $2 \mathbf{D}_{\mathbf{1 0}}$ Value for total bacterial count, total coliforms and total Salmonella-Shigella

\begin{tabular}{lll}
\hline S.No & Organisms & $\mathrm{D}_{10}$ value \\
\hline 1 & Total bacterial count & $\leq 0.4$ \\
2 & Total coliforms & $\leq 0.4$ \\
3 & Total Salmonella-Shigella & $\leq 0.4$ \\
\hline
\end{tabular}

reduce (through inactivation or cell death) the microbial concentration by a factor of ten or by one log cycle. Infect, which is the basis principle for producing radiation-sterilized, single-use medical products, is now well established in industries worldwide (Pikaev and Woods 1994). Based on the same principle, the pathogens present in sewage water can also be effectively removed by exposure to high energy radiation. In this study, EB treatment was found to be very effective in reducing the bacterial count, especially total coliforms count to a safe level and the $\mathrm{D}_{10}$ values of the Total Bacterial Count, Total Coliforms and Total SalmonellaShigella was found to be $\leq 0.4 \mathrm{kGy}$ (Table 2) and $1.5 \mathrm{kGy}$ was sufficient for $5 \mathrm{log}$ elimination of total coliforms. (As shown in Figs. 1, 2, 3, 4) The effectiveness of gamma and EB 
Fig. 9 Biodegradable fraction as indicated by increase in $\mathrm{BOD} / \mathrm{COD}$ with an increase in treatment dose

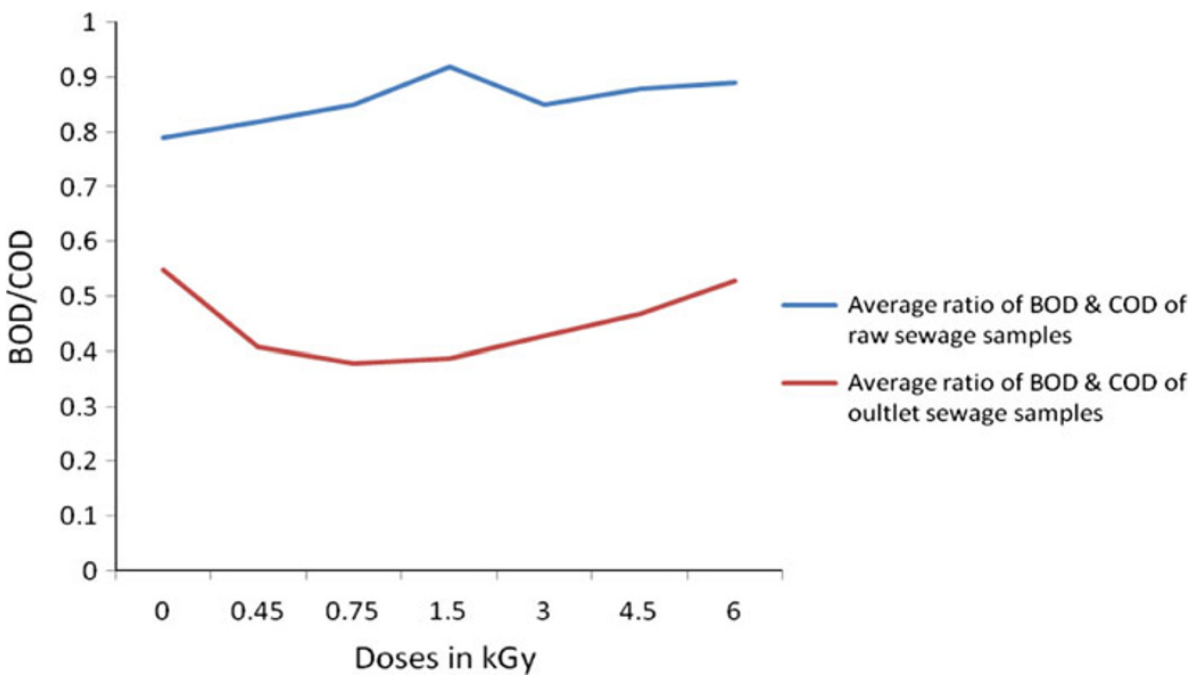

Table 3 Preliminary and rough cost estimation and comparison for disinfection of sewage water (US $\$ / \mathrm{m}^{3}$ )

\begin{tabular}{lllll}
\hline $\mathrm{M}^{3} /$ day & Electron beam & Ozone & UV & Chlorine \\
\hline 10,000 & 0.29 & 0.25 & 0.17 & 0.013 \\
50,000 & 0.073 & 0.086 & 0.171 & 0.013 \\
100,000 & 0.050 & 0.064 & 0.054 & 0.013 \\
200,000 & 0.041 & 0.053 & 0.047 & 0.013 \\
\hline
\end{tabular}

US $\$ / \mathrm{m}^{3}$ Total cost including operation, capacity and discharge water

in eliminating bacterial load was also reported by Basfar and Abdel Rehim (2002) and Rawat et al. (1998).

\section{Sewage water quality improvement by EB treatment}

Biological oxygen demand $\left(\mathrm{BOD}_{5}\right)$

The samples were irradiated with different doses ranging from 0.45 to $6.0 \mathrm{kGy}$. The removal percentage of $\mathrm{BOD}_{5}$ of inlet sewage water sample was increased from 11.11 to 35 for the dose $0.45-6.0 \mathrm{kGy}$ and for outlet water samples the removal of BOD was up to $51.7 \%$ in the case of treatment plant-A as shown in Figs. 5 and 6. Similarly for treatment
plant-B, the percentage of $\mathrm{BOD}_{5}$ was found to be increased from 7.73 to 30.38 in the case of inlet sewage water sample and for outlet water sample it was up to $47.16 \%$ with the same doses as represented in Figs. 7 and 8.

Chemical oxygen demand (COD)

In the present study, it was observed that the rate of COD removal of inlet sewage water sample was increased from 13.20 to 37.54 for the dose 0.45 to $6.0 \mathrm{kGy}$ and for outlet water samples the removal of COD was up to $34.54 \%$ in the case of treatment plant-A as shown in Figs. 5 and 6. Similarly for treatment plant-B, the removal percentage of COD increased from 12.11 to 36.05 for the dose 0.45 to $6.0 \mathrm{kGy}$ in the case of inlet sewage water samples and for outlet water samples the removal of BOD is up to $52.32 \%$ with the respective doses (Figs. 7, 8).

Biological oxygen demand and chemical oxygen demand are the major parameters used as routing surrogate tests for measuring the load of organic carbon into the water environment. In pollution abatement works, organic matter measurement provides a quick and simple method for monitoring pollution levels as well as the accumulation of non-biodegradable or refractory organic materials. The

Table 4 Qualitative comparison of various treatment systems

\begin{tabular}{|c|c|c|c|c|c|c|c|}
\hline $\begin{array}{l}\text { Factor } \\
\text { considered }\end{array}$ & $\begin{array}{l}\text { Activated } \\
\text { sludge plant }\end{array}$ & $\begin{array}{l}\text { Extended aeration } \\
\text { activated sludge }\end{array}$ & $\begin{array}{l}\text { Biological } \\
\text { filter }\end{array}$ & $\begin{array}{l}\text { Oxidation } \\
\text { ditch }\end{array}$ & $\begin{array}{l}\text { Aerated } \\
\text { lagoon }\end{array}$ & $\begin{array}{l}\text { Chlorination for } \\
\text { disinfection }\end{array}$ & $\begin{array}{l}\text { Radiation with electron } \\
\text { beam accelerator }\end{array}$ \\
\hline $\begin{array}{l}\text { Organic matter } \\
\text { removal }\end{array}$ & $\mathrm{F}$ & $\mathrm{F}$ & $\mathrm{F}$ & $\mathrm{G}$ & $\mathrm{G}$ & - & $\mathrm{G}$ \\
\hline FC removal & $\mathrm{P}$ & $\mathrm{F}$ & $\mathrm{P}$ & $\mathrm{F}$ & G & G & EX \\
\hline $\begin{array}{l}\text { Economic } \\
\text { factors }\end{array}$ & $\mathrm{L}$ & $\mathrm{L}$ & $\mathrm{L}$ & $\mathrm{M}$ & $\mathrm{M}$ & $\mathrm{M}$ & $\mathrm{H}$ \\
\hline
\end{tabular}

Adapted from Pereira et al. 2002

$F C$ faecal coli form, $E X$ excellent, $G$ good, $F$ fair, $P$ poor, $H$ high, $M$ medium, $L$ low (e.g. low demanding or low cost) 
efficiency of waste water treatment plants and kinetics characteristics of biological process are usually studied through BOD and COD (Aziz and Tebbutt 1980; Fadini et al. 2004 and Ali Vahdat et al. 2010). In aqueous media, the oxidizing hydroxyl radical $\mathrm{OH}^{*}$, the reducing hydrated electron $\mathrm{e}_{\mathrm{aq}}^{-}$and the hydrogen radical $\mathrm{H}^{*}$ are the predominant products, all of which are highly reactive transient species and are responsible for the various effects including the reduction of pathogens, the oxidation of hazardous organic pollutants and the destruction of molecular structure of targeted pollutants. (Maruthi et al. 2011). The effectiveness of ionizing radiation to remove toxic organic chemicals from aqueous solutions has been already reported by Huaying Bao et al. (2002) and Getoff (1999). The present study revealed that the reduction percentage of BOD and COD of outlet samples was more than the raw sewage samples with same dose $(6 \mathrm{kGy})$ because of other interference like turbidity, total solids and heavy metals etc. which were present in raw sewage before conventional treatment. By the present study it was observed that some of the non-biodegradable fractions got converted into biodegradable fraction as indicated by increase in BOD/COD with an increased treatment dose and it was incredibly effective when sewage contain more organic and inorganic load (shown as Fig. 9).

Moreover, treatment of sewage by combining EB treatment and bioflocculation (TDS will be removed), make waste water fit for both industrial and agricultural purposes.

\section{Economics of sewage water treatment with e-beam}

The conventional treatment of sewage sludge involves stabilization by aeration or digestion (at about $35^{\circ} \mathrm{C}$ ) to reduce the number of pathogens, especially of bacteria such as salmonella by 1 or $2 \log$ units. To obtain a safe hygienic sludge, further reduction of pathogens by about $3 \log$ units is necessary.

Disinfection by chlorination can be problematic in some circumstances. Chlorine can react with naturally occurring organic compounds found in the water supply to produce compounds known as disinfection by-products (DBPs). The most common DBPs are trihalomethanes (THMs) and haloacetic acids (HAAs). Due to the potential carcinogenicity of these compounds, drinking water regulations across the developed world require regular monitoring of the concentration of these compounds in the distribution systems of municipal water systems. The World Health Organization has stated that the "Risks to health from DBPs" are extremely small in comparison with inadequate disinfection (http://www.wikipedia.org).

The design of waste water treatment plant is usually based on the need to reduce organic loads to limit pollution of the environment. Pathogen removal has very rarely been considered as an objective but for reuse of effluents in agriculture, this must be of primary concern. Treatment to remove waste water constituents that may be toxic or harmful to crops, aquatic plants and fish is normally not economically feasible. However, the removal of toxic elements and pathogens that may affect human health needs to be considered (Pereira et al. 2002). Even though our present study is costly, The EB treated sewage water can be effectively used in irrigation as well as in industries as it does not contain any pathogens and some of the physico-chemical parameters are reduced to a safer level (Tables 3, 4).

\section{Conclusion}

In searching for cleaner alternative methodologies, the seed treatment technology using ionizing radiation produced by electron accelerators (electron beam-EB) presents is an environmentally friendly alternative without the use of chemicals. In conventional method, the chlorination of water results in the formation of toxic organo-chlorine products, which are mutagenic and carcinogenic in nature. A preliminary study was conducted to evaluate the effects of electron beam radiation on sewage water. Results obtained at dose rate $(3 \mathrm{kGy})$ were shown to be more efficient for the disinfection of sewage water and at same dose rate showed a substantial improvement in waste water quality with an efficient decrease in organic load that lead to a better bioremediation process. On irradiation, the organic matter in sewage water will be degraded via transforming from complex to simpler molecular forms that are easily metabolized by native soil microflora during irrigation. Therefore, this study stresses the advantage of the use of electron beam radiation for sewage water remediation. Similarly at high dose rate $(6 \mathrm{kGy})$ the removal percentage of organic load in sewage increased up to $50 \%$ of their initial load. Moreover, our study defends the use of ionizing radiation in two ways for treatment of sewage water: lower dose rate for helping bioremediation and disinfection during tertiary treatment process and higher dose rate for reduction of organic load present in sewage water.

Acknowledgments This work was funded by the DAE (Department of Atomic Energy), BRNS (Board of Research on Nuclear Sciences, BARC (Bhabha Atomic Research Centre), India. So we are giving thanks to DAE, BRNS, BARC and GITAM University for utilising facilities. We (first three authors) would like extend our sincere thanks to Sri. A.S.Khader Scientific Officer D, ILU-6 Electron Beam Facility of the Radiation Technology Development Division of the Bhabha Atomic Research Centre, Mumbai., India, for the constant guidance and all the possible help during the irradiation of sewage samples. 
Open Access This article is distributed under the terms of the Creative Commons Attribution License which permits any use, distribution and reproduction in any medium, provided the original author(s) and source are credited.

\section{References}

Ali V, Bahrami SH, Arami M, Motahari A (2010) Decomposition and decoloration of a direct dye by electron beam radiation. Radiat Phys chem 79(1):33-35

American Public Health Association (APHA) (2005) Standard methods for the examination of water and wastewater", 2nd edn

Aziz JA, Tebbutt THY (1980) Significance of COD, BOD and TOC correlations in kinetic models of biological oxidation. Water Res 14(4):319-324

Basfar AA, Abdel Rehim F (2002) Disinfection of wastewater from a Riyadh Waste water Treatment Plant with ionizing radiation. Radiat Phys chem 65:527-532

Borrely SI, Cruz AC, Delmaestro NL, Sampa MHO, Somessari ES (1998a) Radiation processing of sewage sludge: a review. Prog Nucl Energy 33:3-21

Borrely SI, Del Mastro NL, Sampa MHO (1998b) Improvement of municipal wastewaters by electron beam accelerator in Brazil. Radiat Phys chem 52:333-337

Casimiro MH, Leal JP, Gil MH, Botelho ML (2008) Gamma radiation induced effects on slaughterhouse wastewater treatment. Radiat Phys chem 77:98-100

Drzewicz P, Gehringer P (2005) The radiolytic degradation of the widely used herbicide dicamba (3, 6-dichloro-2-methoxybenzoic acid), employing gamma irradiation in laboratory batch conditions and with a beam of accelerated electrons in flow-through installation. Arch Environ Contam Toxicol 48:311-322

Fadini PS, Jardim WF, Guimaraes JR (2004) Evaluation of organic load measurement technologies in a sewage and waste stabilisation pond. J Braz Chem Soc 15(1):131-135

Getoff N (1999) Radiation chemistry and the environment. Radiat Phys chem 54:377-384
Huaying Bao, Yuanxia Liu, Haishun Jia (2002) A study of irradiation in the treatment of wastewater. Radiat Phys Chem 63(3):633

Klieber A, Bagnato N, Barrett R, Sedgley M (2002) Effect of postripening nitrogen atmosphere storage on banana shelf life, visual appearance and aroma. Postharvest Biol Technol 25:15-24

Maruthi AVASN Y, Lakshmana Das N, Hossain K, Sarma KSS, Rawat KP, Sabarwal S (2011) Advance oxidation of sewage water, reclamation and hygienization by radiation technology: a novel approach. Hydrol Curr Res 2(1):108

Meeroff Daniel E, Thomas D, Waite PE, ASCE M, Junko K, Kurucz Charles N (2004) Radiation-assisted process enhancement in wastewater treatment. J Environ Eng 130(2):155-166

Parker JA, Darby JL (1995) Particle-associated coliform in secondary effluents: shielding from ultraviolet light disinfection. Water Environ Res 67:1065-1075

Pereira LS, Cordery I, Iacovides I (2002) Coping with water scarcity. UNESCO IHP VI, Technical Documents in Hydrology 58. UNSCO, Paris

Pikaev AK, Woods RJ (1994) Applied radiation chemistry: radiation processing. John Wiley and Sons Inc, New York

Rawat KP, Sharma A, Rao SM (1998) Microbiological and physio chemical analysis of radiation disinfected municipal sewage. Water Res 32(3):737-740

Shathele MS (2009) Effects of gamma irradiation on fungal growth and associated pathogens. Res J Environ Toxicol 3:94-100

Shaukat F, Kurucz Charles N, Thomas Waite D, Cooper William J (1993) Disinfection of wastewaters: high-energy electron vs gamma irradiation. Water Res 27(7):1177-1184

Sommers CH, Glenn B (2006) Variations in the radiation sensitivity of foodborne pathogens associated with complex ready-to-eat food products. Radiat Phys chem 75:773-778

Spinks JWT, Woods RJ (1990) An introduction to radiation chemistry, 3rd edn. John-Wiley and Sons Inc., New York. ISBN 0-471-61403-3. 574 Seiten, Preis: DM 91, 45

Wang J, Wang J (2007) Application of radiation technology to sewage sludge processing. J Hazard Mater 1(2):2-7 